Our Nature (2006)4:1-9

\title{
Modeling Phosphorus Utilization by Biotic Components: A Test Case Using Two Insoluble Phosphate Sources
}

\author{
D.Chakrabarty \\ Limnology Research Unit,Department of Zoology,Krishnagar Government College \\ Krishnagar -741101, Nadia, West Bengal, India
}

Received: 21.10.2006, Accepted: 15.11.2006

\begin{abstract}
Natural resource management for sustainable development is urgently required in our society and an adequate model is required for quantification of function of natural ecosystem. A simplistic approach has been tried here to quantify phosphorus utilization by biotic components. Two laboratory experiments were conducted to evaluate the amount of $\mathrm{P}$ utilization from two different types of sparingly soluble phosphate rock by aquatic biotic communities. The first type was Mussoorie Phosphate Rock or MPR (sedimentary in origin) and other was Purulia Phosphate Rock or PPR (igneous in origin). The two trials were with eight different treatment combinations. Among various treatments, fish and Chironomid larvae contributed to some extent in increasing the available sediment phosphate content, which in turn increased the soluble reactive phosphate (SRP) of overlying water. The SRP of overlying water decreased in the treatment with zooplanktons. Depletion of SRP of overlying water due to uptake of orthophosphate by Chlorella was also observed. The sedimentary type phosphate rock proved to be more efficient in releasing phosphate than igneous type.
\end{abstract}

Keywords: Chironomid larvae, Chlorella, Fish, Phosphorus model, Zooplanktons.

\section{Introduction}

Phosphorus is an important constituent of biological systems. It is a macronutrient but its availability is often extremely low (Hupfer et al., 2004). Usually phosphorus occurs in oxidized state, either as ions of inorganic orthophosphate or in organic compounds. Phosphorus (P) in solution is normally considered to be Soluble Reactive Phosphate (SRP), which is taken up by different component members of an aquatic ecosystem. Boyd and Musig (1981) demonstrated that plankton in fish ponds absorbed an average of $41 \%$ of a $0.30 \mathrm{mgl}^{-1}$ addition of orthophosphate within 24 hours, however phosphorus that is not absorbed by plankton is rapidly absorbed by mud (Hupfer et al., 2004; Cade-Menum, 2005).
Pelagic invertebrates not only transform but they can also translocate the recycled phosphorus within the system (Shapiro, 1984).

Phosphorus is a recognized nutrient for pond fertilization. The fish ponds in India usually suffer from phosphorus depletion and thereby affect the fish production profoundly. Supply of phosphorus through chemically processed fertilizer in pond water is a common practice in this country. But addition of costly and chemically processed fertilizer degrades the sediment base and overlying water of any aquatic impoundment in long term use (Jhingran, 1997). So, use of indigenous natural Pfertilizer (appetite-P) will save the 


\section{Chakrabarty / Our Nature (2006)4:1-9}

environment from degradation and reduce the financial load from poor fish farmers.

Among various phosphatic fertilizers naturally occurring phosphate source (Mussoorie Phosphate Rock $=$ MPR and Purulia Phosphate rock= PPR) can easily be used in fish farming ponds and has been amply proved to be an effective fertilizer in carp culture (Chakrabarty, 2006). The problem is its extremely low solubility in water. An attempt has been made here to quantify the difference of phosphorus utilization performances by various biotic members in laboratory condition from a marine sedimentary (MPR) and igneous (PPR) phosphate rock of Indian origin.

\section{Materials and methods}

In order to determine the extent of Putilization from MPR and PPR by the major biotic components of the pond ecosystem, two separate laboratory experiments were conducted in the presence of water, MPR and PPR all throughout in 31 glass jars.

For the first trial, 32 glass jars were filled with ground water and then subjected to following eight treatments in quadruplicate. (i) Water - $\left(\mathrm{A}_{1}\right)$, (ii) Water $+\mathrm{MPR}-\left(\mathrm{B}_{1}\right)$, (iii) Water + Soil $-\left(\mathrm{C}_{1}\right)$, (iv) Water + Soil + MPR - $\left(\mathrm{D}_{1}\right)$, (v) Water + Soil + MPR + Chlorella sp. $-\left(\mathrm{E}_{1}\right),(\mathrm{vi})$ Water + Soil + MPR + Zooplankton - $\left(\mathrm{F}_{1}\right)$, (vii) Water + Soil + MPR + Chironomid larvae - $\left(\mathrm{G}_{1}\right)$, (viii) Water + Soil + MPR + Fish $-\left(\mathrm{H}_{1}\right)$. Similar set was was used in the second trial in the presence of PPR as follows (i) Water - $\left(\mathrm{A}_{2}\right)$, (ii) Water + PPR $-\left(\mathrm{B}_{2}\right)$, (iii) Water + Soil $\left(\mathrm{C}_{2}\right)$, (iv) Water + Soil + PPR $-\left(\mathrm{D}_{2}\right)$, (v) Water + Soil + PPR + Chlorella sp. $-\left(\mathrm{E}_{2}\right)$, (vi) Water + Soil + PPR + Zooplankton $\left(\mathrm{F}_{2}\right)$, (vii) Water + Soil $+\mathrm{PPR}+$ Chironomid larvae $-\left(\mathrm{G}_{2}\right)$, (viii) Water + Soil + PPR + Fish $-\left(\mathrm{H}_{2}\right)$. The source of ground water was a deep-tube well. Agricultural soil ( $\mathrm{pH}$ 7.1) was collected from nearby virgin field, where no fertilizer schedule was practiced. Environmental temperature remained 15$18^{\circ} \mathrm{C}$ during the conduction of the experiment

20 gm of hundred mesh size ground MPR (trial-I) and PPR (trial-II) was placed in each of the experimental jars containing 2.51 of ground water ( $\mathrm{pH}$ 7.2). Chlorella $\mathrm{sp}$. used in this experiment was procured from the laboratory axenic monoalgal culture (Chu- 10 medium). When the Chlorella concentration attained about 40 mgl-1 of Chl- a; $10 \mathrm{ml}$ of such concentration was dispensed in each experimental jar of treatment combination of $\mathrm{E}_{1}$ and $\mathrm{E}_{2}$. Daphnia sp. was collected from the culture tank and concentrated to150 numbers and used in each jar. Chironomid larvae (average length $0.5 \mathrm{~cm} \pm 0.025$ ) were locally procured and then acclimatized in the laboratory prior to their use in experiment $\left(\mathrm{F}_{1}\right.$ and $\mathrm{F}_{2}$ ). Thirty Chironomid larvae were used in each glass jar of treatment combination of $\mathrm{G}_{1}$ and $\mathrm{G}_{2}$. Advanced fries of Oreochromis mossambicus $(4.20 \mathrm{~g} \pm 0.25 \mathrm{~g} ; 4.0 \mathrm{~cm} \pm 0.60)$ were procured and acclimatized well in the laboratory prior to their use. Three acclimatized fries were then placed in each glass jar in the treatment combination of $\mathrm{H}_{1}$ and $\mathrm{H}_{2}$. Each set of glass jar was left for 0,7 and 14 days for the examination of phosphorous contents of water, soil and Chlorella sp. All of them were carefully isolated, dried in hot air oven, grinded and total $\mathrm{P}$ content was measured using the method described by Jackson (1967). Chlorophyll-a (Chl- a) concentration of Chlorella sp. was analyzed following the method described by Vollenweider (1974). The soluble reactive phosphate (SRP) concentration of water was also measured following standard methods (APHA, 2002). 


\section{Chakrabarty / Our Nature (2006)4:1-9}

The results were statistically analysed using Kruskal-Wallis one way analysis of variance and Duncan's Multiple Range Test (Duncan, 1955) to find significance of difference between every possible pair of treatment of trial-I and trial-II.

The chemical composition of MPR and PPR are shown in Table 1. The MPR is younger in geologic age than PPR (Table 1) and used as a cheap source of direct application fertilizer in fish farming ponds (Chakrabarty, 2006).

\section{Results}

Introduction of fish $\left(\mathrm{H}_{1}\right.$ and $\left.\mathrm{H}_{2}\right)$ and chironomid larvae $\left(G_{1}\right.$ and $\left.G_{2}\right)$ resulted in considerable rise (Figure 1 and 2) of SRP concentration of water $(0.1825$ and $0.1425 \mathrm{mg}$ $\left.\mathrm{I}^{-1}\right)$ and sediments (13.0-12.9 and11.7-11.5 mg $\mathrm{Kg}^{-1}$ ) over other treatments (Figure 3 and 4). Presence of zooplankton $\left(F_{1}\right.$ and $\left.F_{2}\right)$ in the MPR and PPR treatment, on the other hand, caused decline of orthophosphate level of water all throughout. For example, the amount of orthophosphate observed on day $0(0.165$ $\left.\mathrm{mg} \mathrm{l}^{-1}\right)$ declined to $0.0985 \mathrm{mg} \mathrm{l}^{-1}$ in $\left(\mathrm{F}_{1}\right)$ on day 7 ; and finally to $0.065 \mathrm{mg} \mathrm{l}^{-1}$ on day 14 . In the same trend the amount of orthophosphate observed on day $0\left(0.125 \mathrm{mg} \mathrm{l}^{-1}\right)$ declined to $0.0985 \mathrm{mg} \mathrm{l}^{-1}$ in $\left(\mathrm{F}_{1}\right)$ on day 7 ; and finally to $0.065 \mathrm{mg} \mathrm{l}^{-1}$ on day 14 in the glass jars with $\mathrm{F}_{2}$ combination. The result was also true for Chlorella sp. the amount of orthophosphate of water in the MPR treatment with Chlorella sp. $\left(\mathrm{E}_{1}\right)$ declined to $0.07 \mathrm{mg} \mathrm{l}^{-1} 0.05$ on day 7 and further to $0.045 \mathrm{mg} \mathrm{l}^{-1}$ on day 14 , from the initial concentration of 0.165 Similar result was observed with the same treatment combination $\left(\mathrm{F}_{2}\right)$ with PPR (Figure 2). Glass jars with only water $\left(A_{1}\right.$ and $\left.A_{2}\right)$ showed lowest SRP concentration $\left(0.025 \mathrm{mg} \mathrm{l}^{-1}\right)$ of all, all throughout, whereas a stable and relatively high concentration of 0.155 to $0.1425 \mathrm{mg} \mathrm{l}^{-}$
${ }^{1}$ and 0.125 to 0.10 of SRP was maintained in the treatment combination of $\mathrm{B}_{1}$ and $\mathrm{B} 2$.

Kruskal-Wallis one way analysis of variance by ranks showed no significant difference $(\mathrm{H}=10.33 ; \mathrm{P}>0.05)$ of treatment means in the beginning. However, significant difference $(\mathrm{H} \geq 14.16 ; \mathrm{P}<0.05)$ among treatments was seen on day 7 and 14 . Six treatment groups such as $\mathrm{G}_{1}$ and $\mathrm{G}_{2} ; \mathrm{H}_{1}$ and $\mathrm{H}_{2} ; \mathrm{D}_{1}$ and $\mathrm{D}_{2} ; \mathrm{E}_{1}$ and $\mathrm{E}_{2}, \mathrm{~A}_{1}$ and $\mathrm{A}_{2} ; \mathrm{C}_{1}$ and $\mathrm{C}_{2}$ did not differ from each other on day 7 (Table2 and 3), whereas all the treatment groups expect $C_{1}$ and $C_{2} ; A_{1}$ and $A_{2}$ showed significant difference on day 14 in both the trial. Significant difference was also found between $H_{1}$ and $H_{2}$ as well as $G_{1}$ and $G_{2}$ in respect of concentration of water SRP and sediment available $-\mathrm{P}($ ANOVA, $\mathrm{P}<0.05)$ on $0,7,14$ days of observation. The treatment combination with MPR always showed higher dissolution of $\mathrm{P}$ from insoluble P than the combination with PPR.

The amount of Chl-a concentration (Figure 5) did not varied significantly (ANOVA, P> 0.05) between the two treatment combination $\left(\mathrm{E}_{1}\right.$ and $\left.\mathrm{E}_{2}\right)$ throughout the experimental period. However, the total amount of phosphorus in chlorella (cell-P) was $0.05 \pm 0.002 \mathrm{mg} \mathrm{Jar}^{-}$ ${ }^{1}$ in day 0 of both trial-I and- II. The amount increased to $0.08 \pm 0.002 \mathrm{mg} \mathrm{Jar}^{-1}\left(\operatorname{trial}^{-\mathrm{I}}\right)$ ) and to $0.078 \pm 0.003 \mathrm{mg} \mathrm{Jar}^{-1}$ (trial-II) on day 7 but declined to $0.065 \pm 0.002 \mathrm{mg} \mathrm{Jar}^{-1}$ (trial-I) and to $0.062 \pm 0.003 \mathrm{mg} \mathrm{Jar}^{-1}$ (trial II) in day14. The cell-P also did not varied significantly in any day between two series.

\section{Discussion}

Phosphorus (P) is the most studied element in aquatic system primarily due to the fact that it is the most limiting factor for primary productivity in water bodies is essential for 
D. Chakrabarty / Our Nature (2006)4:1-9

Table 1. Chemical data and characteristics of the two apatite sources (MPR and PPR) tested for their comparative efficiency in releasing phosphorus in laboratory condition. (Analyzed at International Fertilizer Development Corporation, Alabama, USA)

\begin{tabular}{|l|c|c|}
\hline \multicolumn{1}{|c|}{ Major constituents \% } & Mussoorie Phosphate Rock (MPR) & $\begin{array}{c}\text { Purulia Phosphate Rock } \\
\text { (PPR) }\end{array}$ \\
\hline $\mathrm{P}_{2} \mathrm{O}_{5}$ & 21.2 & 21.6 \\
\hline $\mathrm{CaO}$ & 38.5 & 39.4 \\
\hline $\mathrm{Fe}$ & 4.0 & 9.2 \\
\hline $\mathrm{MgO}$ & 5.6 & 5.8 \\
\hline $\mathrm{S}$ & 4.0 & 9.5 \\
\hline $\mathrm{SiO}_{2}$ & 6.6 & 8.1 \\
\hline $\mathrm{C}($ Organic) & 1.14 & 0.92 \\
\hline $\mathrm{F}$ & 2.0 & 4.1 \\
\hline $\mathrm{Characteristics}$ & 9.367 & 9.371 \\
\hline Unit cell dimension, a- axis, $\mathrm{A}^{0}$ & 0.052 & 0.013 \\
\hline Mole ratio $\left(\mathrm{CO}_{3}: \mathrm{PO}_{4}\right)$ & Mussoorie Phosphate Rock (MPR) & Purulia Phosphate Rock (PPR) \\
\hline Origin and nature & apatite & Igneous and fluorapatite \\
\hline
\end{tabular}

Table 2. Results of Kruskal-Wallis one way analysis by ranks $(\mathrm{H})$ and Duncan's Multiple Range Test for mean values of SRP concentration of water in trial-I.

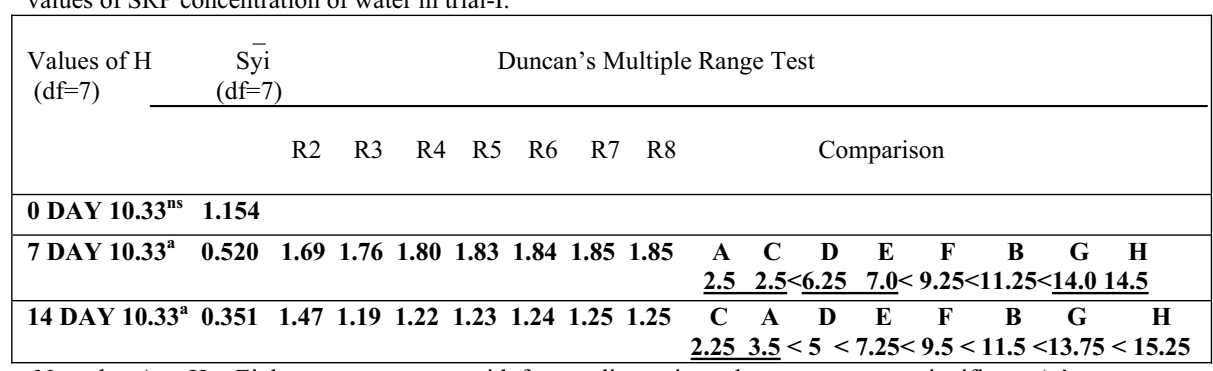

Note that:A to $\mathrm{H}=$ Eight treatment group with four replicates in each group; ns = not significant; 'a' = significant at $5 \%$; Horizontal bar indicates no significant differences

Table 3. Results of Kruskal-Wallis one way analysis by ranks (H) and Duncan's Multiple Range Test for mean values of SRP concentration of water in trial-II.

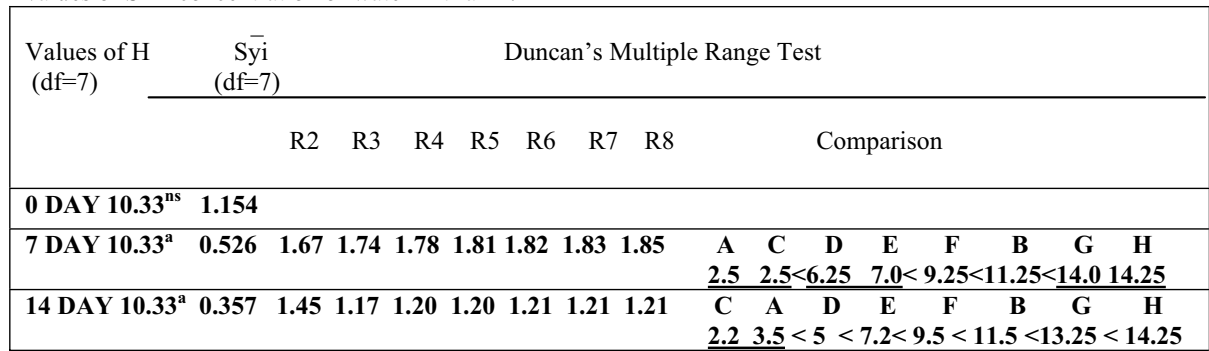

Note that:A to $\mathrm{H}=$ Eight treatment group with four replicates in each group; ns = not significant; 'a' = significant at $5 \%$; Horizontal bar indicates no significant differences 
D. Chakrabarty / Our Nature (2006)4:1-9

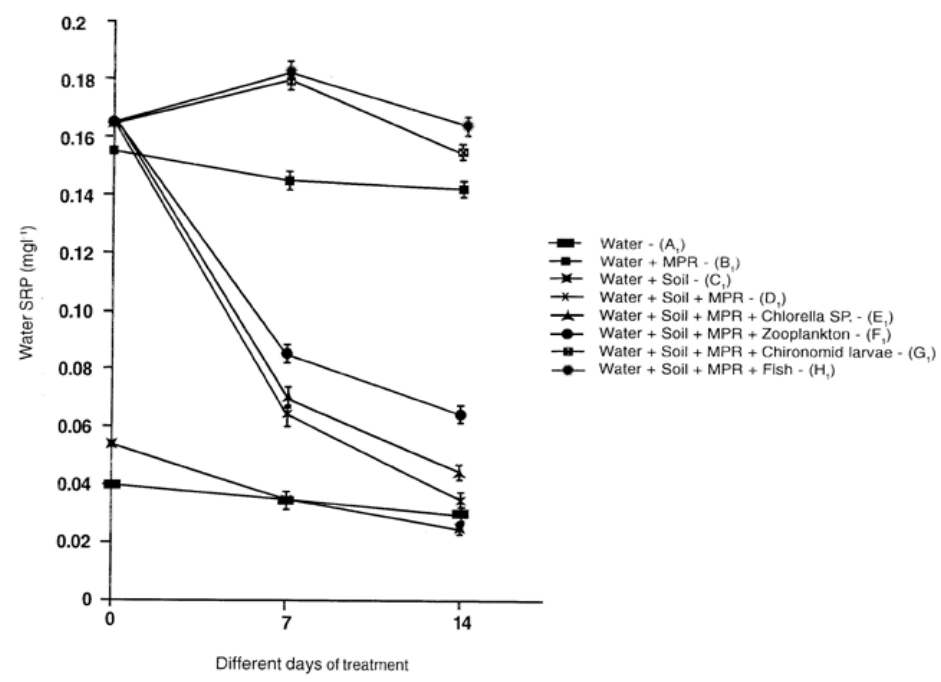

Figure 1. Mean (+ S.D) concentration of soluble reactive phosphate of water in different days of various days of trial I

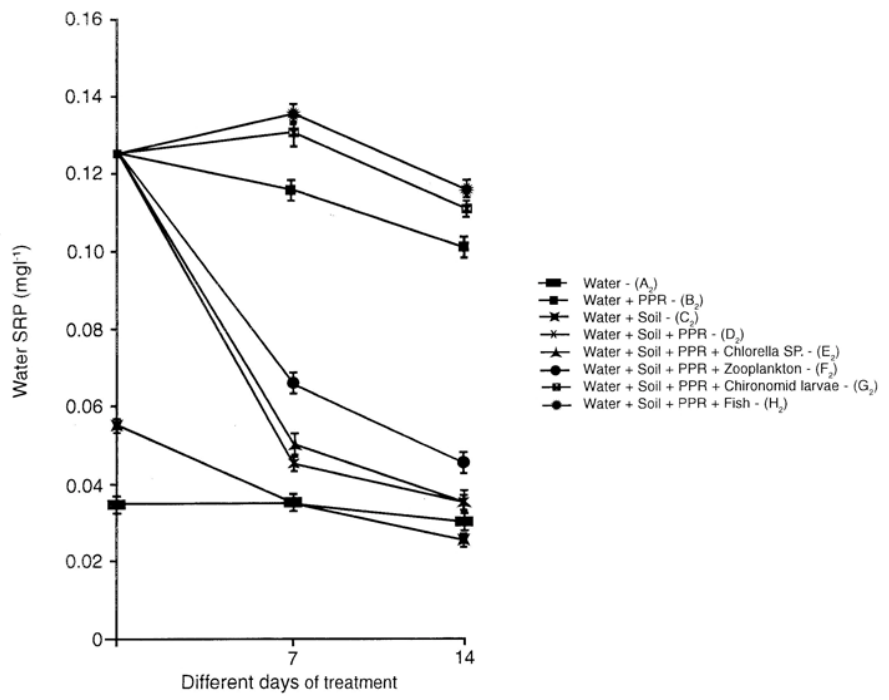

Figure 2. Mean (+ S.D) concentration of soluble reactive phosphate of water in different days of various days of trial II 
D. Chakrabarty / Our Nature (2006)4:1-9

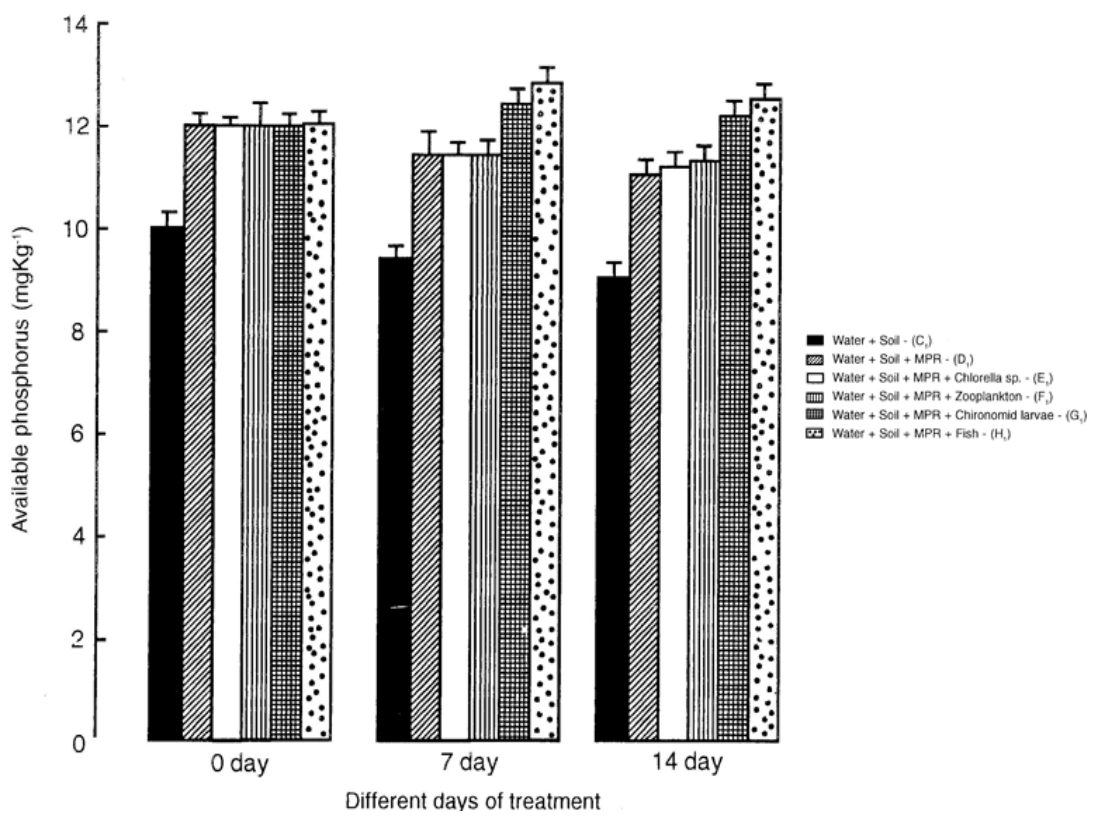

Figure 3. Mean (+ S.D) concentration of available phosphorus in sediment of various treatment of trial

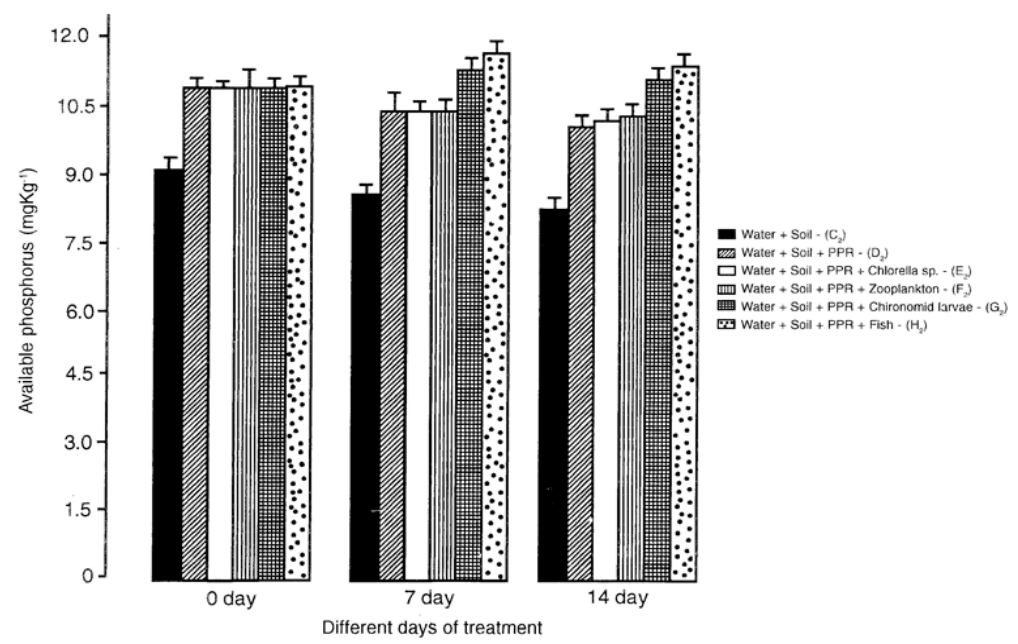

Figure 4. Mean (+ S.D) concentration of available phosphorus in sediment of various treatment of trial 
D. Chakrabarty / Our Nature (2006)4:1-9

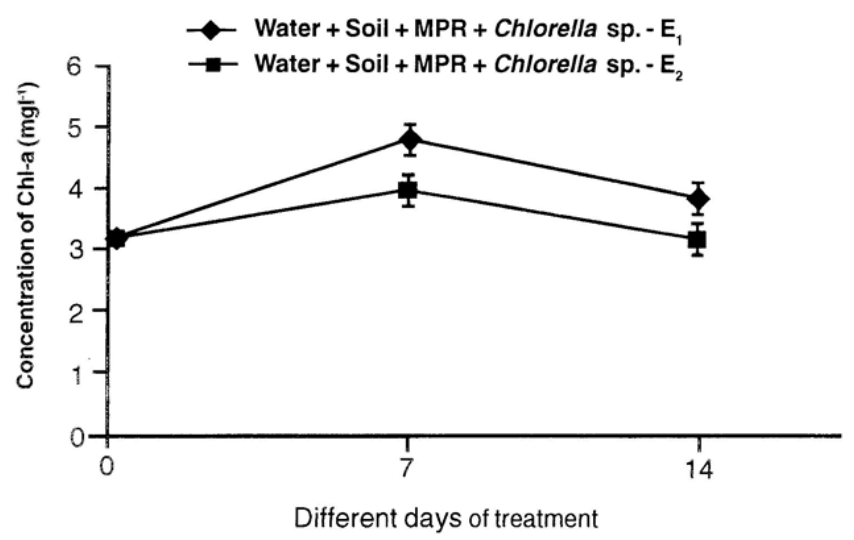

Figure 5. Mean (+ S.D) concentration of chlorophyll-a in days of trial $E_{1}$ and trial $E_{2}$

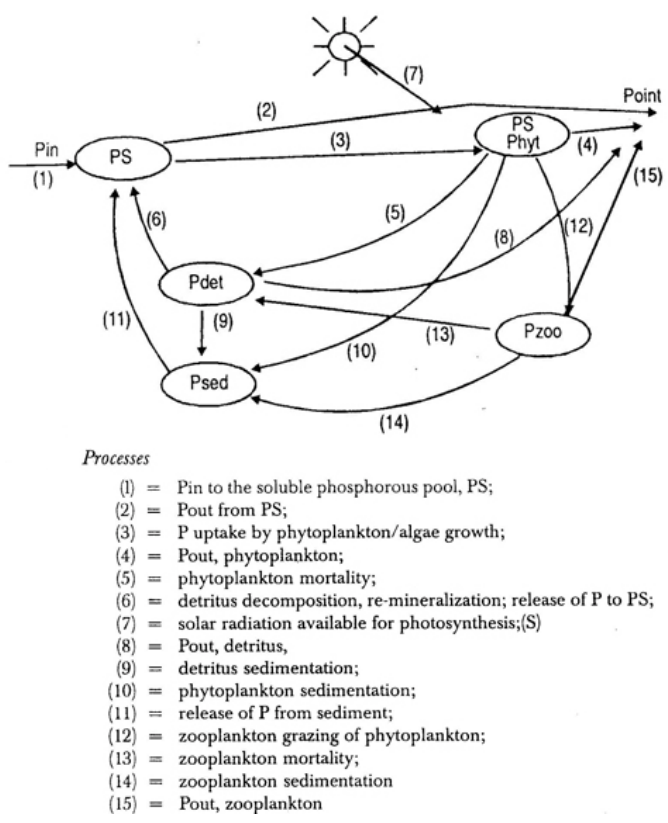

Figure 6. Model describing movement of phosphorus in the aquatic ecosystem 


\section{Chakrabarty / Our Nature (2006)4:1-9}

living organisms and is not exchangeable with other elements in biological system. From the critical examination of the data it was revealed that fish and chironomid larvae contributed to some extent in increasing the available phosphate content of sediment which, in turn, increased the orthophosphate level of overlying water. This was due to their physical disturbance of the bottom sediments which induced the phosphorus release from sediment to the overlying water. The effect was perhaps brought about by the physical disturbance (Petr, 1977) and agitation of sediment enriched with phosphate rock. Similar results were obtained by Gabet et al., (2003), Schauser et al., (2003) and Sondergaard et al., (2003). Biomanupulation trials clearly revealed that fish and chironomid larvae had a profound influence in the release of phosphate from otherwise insignificantly soluble phosphate rock by bioturbation (Chakrabarty, 2006).

There was an increase in biomass of Chlorella evident from the rise in Chlcontent. The depletion in orthophosphate level of water $\left(0.165-0.07 \mathrm{mg} \mathrm{l}^{-1}\right)$ was due to the phosphorous uptake by the Chlorella. This was evident from the increase in cell-P of Chlorella over time. Phosphorous was found to be a growth regulatory factor of algae by Ahlgren (1988). The critical examination of difference in liberation of available phosphorus from the two sparingly soluble phosphate sources indicated a significant difference $(\mathrm{P}<0.05)$ in treatment combination of $\mathrm{H}_{1}-\mathrm{H}_{2}$ and $\mathrm{G}_{1}-\mathrm{G}_{2}$. This was because of the lesser unit cell dimension $\left(>.008 \mathrm{~A}^{0}\right)$ of MPR than PPR (Table 1) as well as the higher $\mathrm{CO}_{3}: \mathrm{PO}_{4}$ mole ratio of (0.052) of MPR than PPR (0.013). As lesser unit cell dimension and higher $\mathrm{CO}_{3}: \mathrm{PO}_{4}$ mole ratio helps in natural dissolution of phosphate rock in natural condition (PPCL 1987). The utilization of phosphorus by Chlorella indicated no significant difference between the treatment combinations of $F_{1}$ and $F_{2}$ Possibly, the amount of SRP was sufficient in both the treatments for algal growth. The concentration of cell $\mathrm{P}$ was also similar between two series. The study indicated that MPR is better phosphate fertilizer than PPR in terms of releasing phosphorus in aquaculture. It also proved that sedimentary phosphate rock has better applicability than igneous type. In an X- ray diffraction studies by PPCL, MPR was identified as carbonate apatite and PPR as fluorapatite. Carbonate apatite is more responsive to natural dissolution than fluorapatite (PPCL, 1987). However, both the fertilizer can be used as direct application fertilizer in fish farming ponds with bottom grazing fishes as a cheap $P$ fertilizer.

\section{References}

APHA (American Public Health Association) 2002. Standard Methods for the Examination of Water and Waste Waters, $21^{\text {st }}$ ed. Am. Publ. Hlth. Assoc., Washington DC, USA.

Ahlgren, G. 1988. Phosphorus as growth regulating factor relative to other environmental factors in cultured algae. Hydrobiologia 170: 191-200.

Boyd, C. E. and Y. Musig 1981. Orthophosphate uptake by phytoplankton and sediment. Aquaculture 22: 165-173.

Cade-Menum, B. 2005. Using phosphorus-31 nuclear magnetic resonance spectroscopy to characterize organic phosphorus in environmental samples. In Organic phosphorus in the environment (Eds. B.L. Turner, E. Frossard and D. S. Baldwin), CABI publishing, Wallingford, pp. 21-44.

Chakrabarty, D. (in Press). Application of phosphate rock in carp culture. MKK Publication, ISSN 09700420, India.

Duncan, D. B. 1955. Multiple Range and Multiple F Tests. Biometrics 1(1): 1-43.

Hupfer, M., B. Rübe and P. Schmieder 2004. Origin and diagenesis of polyphosphate in lake sediments: A ${ }^{31}$ P NMR study. Limnol. Oceanogr. 49: 1-10.

Gabet, J. E., O. J. Reichman and W. E. Seabloom 2003. The effects of bioturbation on soil process 


\section{Chakrabarty / Our Nature (2006)4:1-9}

and sediment transport. Annual Review of Earth and Planetary Sciences 31: 249-273.

Jackson, M. L. 1967. Soil chemical analysis. Prentice Hall of India.

Jhingran V. G. 1997. Fish and Fisheries of India, $2^{\text {nd }}$ ed Hindustan Publishing Corporation, New Delhi, 666 p.

Petr, T.1977. Bioturbation and exchange of chemicals in the mud water interface.In Interactions between sediments and fresh water (Ed. H.L Golterman), The Hague. pp. 216-226

PPCL, 1987. Mussoorie Phos: A natural phosphatic fertilizer for direct application. Pyrites, Phosphates and Chemicals Ltd. New Delhi.

Schauser, I., J. Lewandowski and M. Hupfer 2003.
Decision support for the selection of an appropriate in-lake measure to influence the phosphorus retention in sediments. Wat. Res. 37: 801-812.

Shapiro, J. and R. Carlson 1982. Comment on the role of fish in regulation of phosphorus availability in lakes. Can. J. Fish. Aquat. Sci. 39: 364.

Sondergaard, M., J. P. Jensen and E. Jeppesen 2003. Role of sediment and internal loading of phosphorus in shallow lakes. Hydrobiologia 506509: 135-145.

Vollenweider, R. A.1974. A manual on methods of measuring primary production in aquatic environment. IBP Handbook No. 12, Second Ed., Blackwell Scientific Publications, Oxford, 225pp. 